TURIZAM

Volume 25 , Issue 2

83-95 (2021)

ORIGINAL

SCIENTIFIC PAPER

\title{
Tourists Approaches to Eco-Friendly Hotels and Determination of Green Hotel Preferences: The Case of Eskişehir
}

\author{
Emre Ozan Aksöz ${ }^{A^{*}}$, Birgül Aydın ${ }^{B}$, EsinYücel ${ }^{C}$ \\ Received: October 2020 | Accepted: March 2021 \\ DOI: $10.5937 /$ turizam25-28792
}

\begin{abstract}
The aim of this study is to determine how eco-friendly applications have an impact on the purchasing behaviour of tourists and hotel preferences. In this context, the related data was obtained from 408 participants. T-test was applied in order to determine the impact on the purchasing behaviour of tourists and hotel preferences. As a result of the analysis, it is determined that the majority of the tourists are sensitive about the environment by taking into account eco-friendly hotel accommodation preference and eco-friendly hotels are pioneer in developing new technologies, high qualified, happy to stay in eco-friendly hotels, and eco-friendly hotels evoke nature. Also, it is found that eco-friendly hotels evoke health and wellness. These findings provide an insight into literature and new directions and suggestions for marketing organizations and business managers.
\end{abstract}

Keywords: environment, green marketing, hotel industry, eco-friendly, sustainable tourism, preferences, tourist approaches

\section{Introduction}

Today, the main problem of many countries is to create an environment that can provide a sufficient level of living for the rapidly growing population through the means of scarce natural resources and financing available. In order to achieve high prosperity, countries have entered into the search for various economic models and types.While using natural resources which are indispensable inputs of all economic models for this purpose, they ignored that there is a limit of use of these resources, and if this limit is exceeded, it cannot be balanced, and this was not considered sufficiently.

\footnotetext{
A Anadolu University, Tourism Faculty, Department of Tourism Management, Yunus Emre Campus, Eskisehir, Turkey

B Dogus University, Art and Design Faculty, Department of Gastronomy and Culinary Arts, Istanbul, Turkey

Akdeniz University, Mediterranean Civilizations Research Institute, Antalya, Turkey

Corresponding author: ozana@anadolu.edu.tr
} 
Enterprises producing goods and services are considered as one of the basic institutions that form the social system. In other words, they are obliged to fulfil their responsibilities towards the society they are in. It is essential to fulfil these responsibilities in tourism. Tourism is an important sector in terms of cultural advancement and development but can destroy its own resources (Tsaur et al., 2006). The historical and natural values that form the tourism potential can only create resources for the sector to the extent that they can be protected. In response to mass tourism, the focus is on the interaction between nature, human-environment and tourism activities to protect ecological balances on the basis of the ecological tourism that emerged after industrialization. In contrast to the model aiming to meet all the expectations of the tourists within a limited area, the dynamics of this model are determined not by human but the nature. It is a desired point if the tourism sector grows in this direction. Increasing the number of tourism enterprises that develop strategies for sustainable growth will also contribute positively to tourism sectors commercial growth. This development in tourism causes companies to change their marketing understanding along with their management strategies. In other words, the foundations of sustainable tourism have started to be laid in the presentation of products and services. In this context, hotel managements that continue their hospitality activities began to understand the importance of green marketing concept and started to give priority to green marketing activities in terms of sustainability as both as an application and as a marketing and promotion tool (Xiao, McCright, 2015). The aim of the research is to examine the behaviour of tourists in environmentally friendly hotels and to determine how eco-friendly applications have an impact on the purchasing behaviour of consumers and hotel preferences.

\section{Sustainable Tourism Concept}

Increasing environmental awareness has caused tourism to be seen as a major environmental problem (Urr, 1995). It is obvious that an unhealthy and poorly planned tourism development will partially or completely erode the quality of the natural environment and man-made environment that attract visitors. Such negative developments lead to commercial and social costs. Especially as a result of the rapid increase in the number of visitors coming to a touristic area, the economic, physical, social and cultural carrying capacities in the area are overloaded. In this case, the development of tourism in related area is slowing down and even falling, negative impacts on the tourism sector, not only the other sectors are affected negatively, and this is reflected in the local people as social costs (Xiao, McCright, 2015). It is necessary to recognise these negative impacts primarily as a general problem at the local, regional and national level, and to pay special attention to the local levels where the impacts and concerns are seen more clearly (Wahid et al., 2011).

In order to decrease the negative effects of tourism to develop a healthy tourism, a concept of "sustainable tourism development" was suggested among others and accepted recently. This concept has been made so far with different statements and explanations. However, since the word "sustainable" is used worldwide and it is a common term, it is in danger of being meaningless. In addition, this term is often not defined and very different forms of use, in the sense that no consensus has been reached (Untaru et al., 2014). In order to define sustainable tourism development, the following concepts must be defined.The concept of sustainability in relation to tourism is to maintain and improve the regional or local characteristics that are the source of tourism and to ensure the continuity of tourism. In other words, regional or local characteristics and cultural and natural values are perceived in the course of daily life (Straughan, Roberts, 1999). Sharma (2014) defines sustainable tourism development to meet 
the needs of existing tourists and local people while preserving future opportunities. Wahid et al. (2011) consider sustainable tourism development as an approach aimed at minimizing environmental and cultural degradation, increasing customer satisfaction and maximizing long-term economic development for the region. The World Tourism Organization (UNWTO) defines sustainable tourism as meeting the needs of today's tourists and host regions, taking into account the protection and development of future opportunities. In this way, "management of all resources" emphasizes cultural integrity, compulsory ecological processes, social and aesthetic needs. Sustainable tourism products are products that are processed in harmony with the local environment, society and cultures that are useful rather than being damaged by tourism development (Sharma, 2014: 29; Peattie, Crane, 2005). When resuming from the above definitions, the sustainable tourism development for life support systems, biological diversification, ecological processes and cultural integration while maintaining the necessary economic, social and aesthetic needs can be fully met in the form of management of all resources in such a way that a general expression can be used. In addition, Becken and Patterson (2006: 324 ) identifiedthatthe tourism sectorcontributed to annual energy use (between 25 and $28 \mathrm{PJ}$ ) and $\mathrm{CO}_{2}$ emissions (between 1400 and $1600 \mathrm{kt}$ ).

According to statistics, the energy consumed by a guest per day in hotels is $130 \mathrm{Mj}$ and $\mathrm{CO}_{2}$ emissions per day are $20.6 \mathrm{~kg}$. According to Özkök (2013) it is calculated as 98MJ and $15.6 \mathrm{~kg}$ per day when it is compared with other types of touristic facilities and taken as an average. This shows that hotels among all types of tourist facilities are remarkably high energy consuming structures.. In recent years, concepts such as "Sustainable Tourist Resort", "Green Hotel", which is an extension of this change, have become an issue and have been subject to research all over the world. This topic is discussed in more detail below.

\section{Concept of Green Marketing}

The term green marketing was firstly suggested by American Marketing Association in 1975. The concept of green marketing according to the recognition made by the American Marketing Association is the negative or positive effects of marketing activities on environmental pollution, energy consumption and consumption of other resources (Wahid et el., 2011: 44; Peattie, Crane, 2005:360). In this context, it is expressed as an understanding adopted by enterprises that consider the ecological environment as an important element in decision-making processes, aim to minimize or eliminate the damage caused to the environment in their activities, and that change the design and packaging of products, production processes, and attempt to place the ecological protection philosophy in business culture (Untaru et al., 2014: 89).

Consumers prefer products that do not harm the environment and force businesses to develop strategies in this direction. Around 43 million tourists worldwide are said to have identified themselves as environmentalists, consciously preferred eco-friendly facilities and willing to pay more for eco-friendly services (Machaira et al., 2012). The results of the survey conducted by TripAdvisor (2012) with over 700 participants showed that $71 \%$ of American tourists plan more eco-friendly holidays than in the previous year and half tend to spend more money on eco-friendly accommodation. Gil et al. (2001) demonstrated that hotels with proactive environmental management approach will be superior to annual profitability and occupancy rates compared to other hotels. Green marketing research shows that enterprises add strength to their corporate image and increase the acceptability in the perception of consumers (Peattie, Crane, 2005: 361). In this context, it is very important that accommodation companies use environmentally conscious practices as a marketing tool. 
Green marketing dates back to theearly 1970 (Polonsky, 1994). Intheearly 1990s, many different aspects of green marketing were discussed academically. It was concluded that more research was needed on, for example, promotion and consumer needs (Park, Sohn, 2012). However, the main focuses of the green marketing literature in the late 1980 and early 1990 os came almost exclusively to be the size of the green market and the 'profile' of the green consumer. The product, one of the important elements of marketing combination, refers to all the presentations offered by businesses or other non-profit organizations to their potential and current customers. In other words, the product is anything that is offered to the market for consumption, use, capture or consideration in order to meet a request or requirement. The products are the main variables that determine the position of a firm in the market (Polonsky, 1994:3). The green product is the product to grow and protect the natural environment by protecting energy and resources or by reducing pollution, waste and toxic substances (Park, Sohn, 2012).

One of the most important decisions for businesses that produce green products or use green products during the service process is to determine the price. The most important factors in determining the price are market conditions and consumers' perception of green products (Paço et al., 2013). In other words, if the price is at the samelevel, the positive environmental characteristics of the product can be a competitive advantage (Mostafa, 2007). Environmental products are produced at additional costs due to the Research \&Development departments' intensive work on reducing energy use during production and efficiency of resource usage. For these reasons, prices can usually be higher than alternatives. Studies have shown that consumers are demanding environmentally sensitive services, but they are not willing to pay more if they do not benefit significantly from these services in response to these demands (Mostafa, 2007). According to Minton and Rose (1997) a lower price at the end of cost savings leads consumers to buy environmentally friendly products. In this respect, when the demand for the product is sensitive to price, a lower price is a more successful strategy for the enterprise.

Distribution can be defined as all of the activities to ensure that the right product can be obtained at the right amount, at the right conditions, at the right place and at the right time and at the right cost for the right customer. The main objective of the distribution is to complete the work at the lowest possible cost in the entire process from production point to consumption point (Khare et el., 2013). In other words, the green product (or services) should aim to minimize the harm to the environment in the process of delivering to the consumer, just as in the process of production. This means that in the green marketing process, a green distribution policy is needed to determine the measures to be taken to protect the environment (Dilek, 2012: 14). One of the conditions for successful implementation of green marketing strategies, distribution channels consisting of wholesalers, brokers and retailers need to be carried out continuously and in a healthy manner to transfer information to the company.

Hotel management practices for sustainable tourism and conservation of nature, called as green hotel management, help both to save energy and to reduce the waste left to nature. Green hotel management is seen as an increasing application of importance in the sector. Competition pressure, attitudes of consumer and non-governmental organizations and environmental protection policies of governments are among the reasons for the green hotel orientation (Khare et al., 2013).

The concept of "green hotel" is emerging as a concept that consumes less energy and water, reduced $\mathrm{CO}_{2}$ emissions, has been built with environmentally friendly local and recyclable materials that have a positive impact on global climate change, and documents the social and environmental responsibility of its investors. The concept of "sustainable hotel", which has become increasingly widespread, has caused a change in hotel design and management in many categories, from boutique hotels to well-known hotel chains worldwide (Kalafatis et al., 1999). 
A study examined the perceptions of tourists towards green hotels. According to the results to be obtained, to save energy, to use environmentally friendly materials and not to use disposable products are the applications that green hotels need to do. In the study, green hotels will benefit both the environment and the hotel guests, but the negative aspects of the accommodation here are high prices and low comfort (Coral, 2016).

Consumers who choose "green hotel" or "green product" are sensitive to environmental issues such as depletion of natural resources, but most of the research has shown that such consumers are afraid to buy green products because they think they are more expensive than other products (Jansson et al., 2010). At the same time, more and more firms are engaging in greenwashing, misleading consumers about firm environmental performance or the environmental benefits of a product or service (Delmas, Burbano, 2011: 64). Greenwashing is the act of misleading consumers regarding the environmental practices of a company (firm-level greenwashing) or the environmentalbenefits of a product or service (product-level greenwashing) (Delmas, Burbano, 2011: 66). The prevalence of greenwashing has skyrocketed in recent years; more and more firms have been combining poor environmental performance with positive communication about environmental performance. Greenwashing can have profound negative effects on consumer and investor confidence in green products and environmentally responsible firms, making these stakeholders reluctant to reward companies for environmentally friendly performance(Delmas, Burbano, 2011: 84).

\section{Materials and Method}

The aim of the research is to examine the behaviour of tourists in environmentally friendly hotels and to determine how eco-friendly applications have an impact on the purchasing behaviour of consumers and hotel preferences. Apart from this main objective, to measure the environmental friendly information of individuals in Eskisehir (Turkey) province, to measure the interest of individuals in environmental friendly hotels and to contribute to the green marketing strategies of hotel enterprises are listed as other objectives of the research.

In this context, in order to achieve the objectives of the research mentioned above, the following research questions wereexamined:

Research Question 1: How do tourists approach the idea of accommodation in eco-friendly hotels?

Research Question 2: How do tourists approach services in eco-friendly hotels?

Research Question 3:What are opinions of tourists on choosing environmentally friendly hotels?

The research was conducted in Tepebaşı and Odunpazarı districts in Eskişehir (Turkey) province in 2018. Eskişehir, located in Central Anatolia is an indus-trial, tourism and transport centre in western Turkey.Eskisehir offers various tourism attractions for tourists with its historical and natural beauties, socio-cultural values, developed urbanism concept, two great universities, attractive life and transport facilities and an attractiveness factor interms of tourism sector (Evren, Kozak, 2012). The reason for the preference of Tepebaşı and Odunpazarı (Eskişehir, Turkey) districts is that the majority of Eskişehir population resides in these districts. According to TUIK (2017) population data, 353,179 people reside in Tepebaşı District older than 18 years of age, and 399,451 people reside in Odunpazarı district. However, due to 
the time and cost limitation experienced in the data collection process, the entire theoretical population cannot be reached. The sample frame was formed by individuals who could be reached in the data collection stage because the number of individuals in the specified time frame and spaces could not be reached in advance.The sample volume of the study was determined by using the calculations given in Table 1 . According to these calculations, it is understood that in quantitative research methods, $95 \%$ confidence level and 384 sample size will be sufficient for the size of the universe consisting of one million.

Table 1. Sample size in quantitative research methods

\begin{tabular}{|c|c|}
\hline & Calculated Size of Sample \\
\hline Universe Size & $\begin{array}{l}95 \% \text { confidence level and heterogeneous } \\
\text { consideration of the universe }\end{array}$ \\
\hline 100 & 80 \\
\hline 500 & 217 \\
\hline 1.000 & 278 \\
\hline 5.000 & 357 \\
\hline 10.000 & 370 \\
\hline 50.000 & 381 \\
\hline 1.000 .000 & 384 \\
\hline
\end{tabular}

Source:Krejcie and Morgan, 1970: 608.

Based on the information given in Table 1 and the calculation using the formula, it is aimed to obtain 384 and above data in order to reach the sample size that can represent the universe in the research. As a matter of the study, no restrictions were observed on the demographic characteristics of the consumers. However, it was the only consideration that the participants giving the answers of "Partially" or "No" to the question "do you know the concept of eco-friendly hotel" were not included and the answer "Yes" was required. The reason for this is based on the belief that it will enable them to act more consciously while filling the questionnaire. Before the study was carried out, an expert group of 20 people was selected and the clarity of the questions was tested. As a result of the 453 questionnaires, 45 questionnaires were found to be incomplete or inaccurate and 408 questionnaires were evaluated.

\section{Data Collection Tool}

The questionnaire was used as a data collection tool in the research. At the beginning of the questionnaire, six questions were asked to determine the demographic characteristics of the participants. In the next section, there are seven more questions about the holiday preferences of the participants. In the last section, the "green marketing" scale, Leonidou et al. (2013) Menon et al. (1999), Middleton and Clarke (2001) and Carmona-Moreno et al. (2004) there are 13 statements compiled for use in hotel facilities. By making confirmatory factor analysis by scale researchers, structure validity has been proven. 13 expressions used with the scale of 5 Likert (1: Definitely agree-5: Definitely disagree) measured.

In order to measure the preference of hotels with green marketing practices, a scale was formed for the purpose of 'eco-friendly is my first choice of hotels', 'eco-friendly hotels I'd recommend it to others', 'I'll continue to stay in hotels, even though the price is high in environmentally friendly', 'eco-friendly hotel I am familiar with', 'environmentally friendly hotels 
suited my personality", 'eco-friendly hotels reliable' and 'eco-friendly hotels in new varieties/ technologies is free to develop" were contained. After the survey questions were determined, the analysis phase of the findings was started with the help of the SPSS 19.o program.

The findings on demographic characteristics of the participants are presented in Table 2 and the findings on holiday preferences are presented in Table 3. It is observed that $55.9 \%$ (228 people) of the participants were male. $59 \%$ (241 people) of the participants are married individuals. $34 \%$ of respondents ( 138 people) were between the ages of $26-33$, followed by $26.8 \%$ (109 people) between the ages of $18-25$.

Table 2. Demographic characteristics of the participants

\begin{tabular}{|c|c|c|c|}
\hline \multicolumn{2}{|c|}{ Demographic Characteristics } & \multirow{2}{*}{$\begin{array}{c}\text { Frequency (n) } \\
228\end{array}$} & \multirow{2}{*}{$\begin{array}{c}\text { Percentage (\%) } \\
55,9\end{array}$} \\
\hline \multirow{3}{*}{ Gender } & Male & & \\
\hline & Female & 180 & 44,1 \\
\hline & Total & 408 & 100 \\
\hline \multirow{3}{*}{ Marital Status } & Married & 241 & 59 \\
\hline & Single & 167 & 41 \\
\hline & Total & 408 & 100 \\
\hline \multirow{6}{*}{ Age } & $18-25$ & 109 & 26,8 \\
\hline & $26-33$ & 138 & 34 \\
\hline & $34-41$ & 98 & 24,1 \\
\hline & $42-49$ & 42 & 10 \\
\hline & 50 and older & 21 & 5 \\
\hline & Total & 408 & 100 \\
\hline \multirow{6}{*}{ Education Level } & Primary & 2 & 0,5 \\
\hline & Secondary & 5 & 1,2 \\
\hline & High & 52 & 12,9 \\
\hline & Undergraduate & 272 & 66,5 \\
\hline & Post-graduate & 77 & 18,9 \\
\hline & Total & 408 & 100 \\
\hline \multirow{6}{*}{$\begin{array}{l}\text { Household Monthly } \\
\text { Income (Turkish } \\
\text { Lira=TL) }\end{array}$} & 1603 TLand less & 28 & 6,9 \\
\hline & $1604-3000 \mathrm{TL}$ & 74 & 18,2 \\
\hline & $3001-4500 \mathrm{TL}$ & 110 & 27 \\
\hline & $4501-6000 \mathrm{TL}$ & 97 & 24 \\
\hline & 6001 TLand over & 99 & 24,1 \\
\hline & Total & 408 & 100 \\
\hline \multirow{7}{*}{ Profession } & Private Sector & 170 & 41,9 \\
\hline & Public Sector & 133 & 32,8 \\
\hline & Retired & 9 & 2,2 \\
\hline & Self-employment & 15 & 3,5 \\
\hline & Student & 58 & 14,1 \\
\hline & Not working & 23 & 5,7 \\
\hline & Total & 408 & 100 \\
\hline
\end{tabular}


When the education levels of the individuals included in the sample are examined, it is observed that the majority $(66.5 \%, 272)$ of respondents are undergraduates. When the participants are evaluated for monthly income, it is observed that $27 \%$ (110 people) have an income of 3001-4500TL, $24.1 \%$ (99 people) of 6001TL and more, $24.1 \%$ (97 people) of 4501-60ooTL. In addition, $41.9 \%$ of respondents $(170)$ work in the private sector and $32.8 \%$ (133) in the public sector.

The findings regarding the holiday preferences of the individuals who answered the questionnaire are shown in Table 3. The majority of the participants prefer to spend their holidays in resort hotels $(69.9 \%, 284$ people). The most preferred holiday type is the sea-sand-sun holiday with $54 \%$ (220 people) and the second is the nature holiday (41.8\%; 169 people).

Table 3. Holiday preferences of the participants

\begin{tabular}{|c|c|c|c|}
\hline \multicolumn{2}{|c|}{ Holiday Preferences } & Frequency $(n)$ & Percentage (\%) \\
\hline \multirow{7}{*}{$\begin{array}{c}\text { Accommodation type } \\
\text { to be preferred at } \\
\text { holiday }\end{array}$} & Resort hotel & 284 & 69,9 \\
\hline & Eco-resort & 91 & 22,4 \\
\hline & Health and Thermal Resort & 3 & 0,6 \\
\hline & Hostel & 4 & 1 \\
\hline & City hotels & 25 & 6 \\
\hline & Others & 1 & 0,2 \\
\hline & Total & 408 & 100 \\
\hline \multirow{4}{*}{$\begin{array}{l}\text { Mostly preferred } \\
\text { holiday type }\end{array}$} & Holiday in nature & 170 & 41,8 \\
\hline & Sea sand sun & 220 & 54 \\
\hline & Others & 18 & 4,2 \\
\hline & Total & 408 & 100 \\
\hline \multirow{6}{*}{$\begin{array}{l}\text { Average number of } \\
\text { holidays in a year }\end{array}$} & 1 time & 239 & 58,8 \\
\hline & 2 times & 120 & 29,4 \\
\hline & 3 times & 40 & 9,7 \\
\hline & 4 times & 4 & 1 \\
\hline & 5 times and more & 5 & 1,1 \\
\hline & Total & 408 & 100 \\
\hline \multirow{8}{*}{$\begin{array}{l}\text { Others to be gone on } \\
\text { to holiday }\end{array}$} & Alone & 11 & 2,7 \\
\hline & Spouse & 63 & 15,3 \\
\hline & Children & 4 & 1 \\
\hline & Spouse and children & 180 & 44,1 \\
\hline & Parents & 38 & 9,4 \\
\hline & Friends & 108 & 26,6 \\
\hline & Others & 4 & 1 \\
\hline & Total & 408 & 100 \\
\hline
\end{tabular}

$58.8 \%$ (239) of the individuals in the research averagely buy a holiday once a year. $44.1 \%$ (180 people) of the participants are on holiday with their spouse and children.

The answers of the participants to nominal questions regarding environmental friendly hotel perceptions were subjected to frequency analysis. Table 4 shows that participants believe in the protection of the environment when they are staying at an environmentally friendly hotel. 
Table 4. Participants believing in the protection of environment when they stay in environmentally friendly hotel

\begin{tabular}{|c|c|c|}
\hline & Frequency & Percentage \\
\hline Yes & 314 & 76,9 \\
\hline No & 94 & 23,1 \\
\hline Total & 408 & 100 \\
\hline
\end{tabular}

While $76.9 \%$ of the participants who think they contribute to the protection of the environment by choosing accommodation in an eco-friendly hotel, $23.1 \%$ of all the participants think they do not contribute. According to this, the participants generally think that green hotel applications are beneficial to the environment when they stay in hotels.

Table 5. Willingness of the participants to pay more in an environmentally friendly hotel

\begin{tabular}{|c|c|c|}
\hline & Frequency & Percentage \\
\hline Yes & 280 & 68,9 \\
\hline No & 128 & 31,1 \\
\hline Total & 408 & 100 \\
\hline
\end{tabular}

Table 5 indicates the will to pay more for accommodation in an eco-friendly hotel. According to the table, the rate of participants paying extra prices for eco-friendly products is $68.9 \%$, while the rate of participants stating that they do not pay extra fees is $31.1 \%$.

Table 6. Membership of participants to a environment protection organization

\begin{tabular}{|c|c|c|}
\hline & Frequency & Percentage \\
\hline Yes & 80 & 19,9 \\
\hline No & 328 & 80,1 \\
\hline Total & 408 & 100 \\
\hline
\end{tabular}

Table 6 indicates the membership of the participants to an environmental protection organization. Accordingly, 19.9\% of them is a member toan environmental protection organization and $80.1 \%$ is not. Compared with the importance given to environmentally friendly hotels observed in the two previous tables and the desire to pay more, the participants can comment on their choice of accommodation in environmentally friendly hotels rather than taking beneficial actions in the environment through any organization. 
Table 7. Single sample $t$ test for environment-friendly hospitality management of the participants

\begin{tabular}{|c|c|c|c|c|c|c|c|}
\hline & $n$ & Mean & $\begin{array}{c}\text { Std. } \\
\text { deviation }\end{array}$ & $\begin{array}{l}\text { Std. } \\
\text { error }\end{array}$ & $\begin{array}{l}\text { T test } \\
\text { value }\end{array}$ & $\begin{array}{c}\text { Degree of } \\
\text { freedom (sd) }\end{array}$ & $\begin{array}{c}\text { Degree of } \\
\text { meaning }(p)\end{array}$ \\
\hline $\begin{array}{l}\text { I prefer to stay in environmentally } \\
\text { friendly hotels }\end{array}$ & 408 & 4,08 & ,877 &, 044 & 43,655 & 399 & ,000 \\
\hline $\begin{array}{l}\text { I warn my relatives about hotels } \\
\text { that harm the environment }\end{array}$ & 408 & 3,94 & ,912 & ,046 & 45,133 & 399 &, 000 \\
\hline $\begin{array}{l}\text { I am aware of how eco-friendly } \\
\text { hotels are determined. }\end{array}$ & 408 & 4,22 & ,830 & ,041 & 42,910 & 399 &, 000 \\
\hline $\begin{array}{l}\text { It is very important that } \\
\text { environmentally friendly products } \\
\text { are preferred by consumers for the } \\
\text { protection of nature. }\end{array}$ & 408 & 4,30 & ,796 &, 040 & 42,590 & 399 &, 000 \\
\hline $\begin{array}{l}\text { Eco-friendly products are my first } \\
\text { choice }\end{array}$ & 408 & 3,69 & ,899 &, 045 & 51,254 & 399 & ,00 \\
\hline $\begin{array}{l}\text { I recommend environmentally } \\
\text { friendly products to others }\end{array}$ & 408 & 3,67 & 929 &, 046 & 50,126 & 399 & ,00 \\
\hline $\begin{array}{l}\text { I will stay in environmentally } \\
\text { friendly hotels even if the price is } \\
\text { high }\end{array}$ & 408 & 3,39 & ,962 &, 048 & 54,133 & 399 & ,00 \\
\hline $\begin{array}{l}\text { Eco-friendly hotels suit my } \\
\text { personality }\end{array}$ & 408 & 3,87 & ,927 &, 046 & 45,930 & 399 & ,00 \\
\hline $\begin{array}{l}\text { Environmentally friendly products } \\
\text { are reliable }\end{array}$ & 408 & 3,85 & ,944 &, 047 & 45,595 & 399 & ,00 \\
\hline $\begin{array}{l}\text { Eco-friendly hotels are pioneers in } \\
\text { developing new kinds/technologies }\end{array}$ & 408 & 3,75 & 916 &, 046 & 49,111 & 399 & ,00 \\
\hline $\begin{array}{l}\text { I'm happy to stay in eco-friendly } \\
\text { hotels }\end{array}$ & 408 & 3,70 & ,963 & ,048 & 47,795 & 399 & ,00 \\
\hline $\begin{array}{l}\text { Eco-friendly hotels remind me of } \\
\text { nature }\end{array}$ & 408 & 3,92 & ,923 &, 046 & 44,973 & 399 & ,00 \\
\hline $\begin{array}{l}\text { Eco-friendly hotels remind me of } \\
\text { health and wellness }\end{array}$ & 408 & 4,06 & 1,007 & ,050 & 38,532 & 399 & ,00 \\
\hline
\end{tabular}

According to the results in the Table 7 , the majority of the tourists are sensitive about the environment by taking into account their eco-friendly hotel accommodation preferences, reference the environmental friendly hotels to their and other positive responses given as the consumer groups.

Based on the expressions of the participants, it is understood that they are aware of the environment friendly hotels and they recommend them to others. It is understood from the table that the participants are familiar with eco-friendly hotels, that the eco-friendly hotels are suitable for their personality and that the eco-friendly hotels are reliable. The participants think that eco-friendly hotels are a pioneer in developing new technologies, high quality, and happy to stay in eco-friendly hotels, and that eco-friendly hotels evokes nature. Finally, the participants stated that eco-friendly hotels evokes health and wellness. Apart from their participation, the participants stated that they were hesitant to say, "I will continue to buy environmentally friendly products even if they have a high price." 


\section{Results and Discussion}

Today, the uncontrolled use of natural resources causes the world to alarm in various ways. The world's alarm is being investigated by various communities, institutions and individuals for a long time. While governments were referring to constructive ways, the voices of non-governmental organizations rose, and businesses went to various applications with the fear of being indifferent to the increasing consumer awareness and fear of losing their reputation, and the desire to contribute to the nature in real sense. These practices are carried out by keeping every action taken from the first step in the formation of the products or services to the last step reaching the consumer at least to the extent that it will harm the environment. In the marketing literature, this chain of action, called green marketing, is the marketing strategy implemented by a growing number of businesses including accommodation establishments in tourism sector.

The demographic characteristics of the participants were examined and the general profile of the participants was revealed. Although there is no significant difference in terms of the gender of 408 participants in the survey, it is observed that male participants are predominant. The majority of the participants were married and the most age range was between 18-25 and 26-33 years. This shows that the young population is more interested in sustainable tourism and eco-friendly hotels. It was observed that the participants were mostly university graduates and post-graduate individuals, and they were mostly among the income groups of $3001-4005 \mathrm{TL}$ and $6001 \mathrm{TL}$ and above. Accordingly, participants are composed of well-educated women and men with moderate and good income levels. In addition to this profile, it is observed that most of the participants are public and private sector employees.

In parallel with the purpose of the research, the preferences for accommodation and service reception in environmentally friendly hotels were tried to be understood in various terms. The purchase action can be shaped by factors such as the characteristics and attractiveness of brands, the additional benefits they offer to consumers and the superior level of performance. In this context, the general attitudes of the participants towards the environment, which are an indicator of the preferences in accommodation activities in environmentally sensitive hotels, are the basic structure of their tendencies on the subject. It is observed that the participants prefer environmentally sensitive hotels, the family members that they want to stay in hotels that are less harmful to nature and environment, and show positive attitudes about the subject. Considering that consumers should stay in environmentally friendly hotels for the protection of nature, participants stated that they are aware of environmentally friendly hotels. Participants are convinced that they contribute to the protection of the environment by staying in environmentally friendly hotels. These expressions include actions that can be shaped by the desire of the individual in the purchase action of the individual or in the social relations of the individual. The effort with faith has pushed some participants into actions to gain profit to society and nature without waiting for compensation, while some participants have pushed them into indecision about the issue. 


\section{Conclusion}

The aim of this study is to give a clue how green marketing and environmental awareness can/ will shape hotel preferences for individuals. Respect for the environment and nature is the respect for life. Therefore, the sensitivity and awareness levels of the participants and all the participants will be an indispensable key to a healthy and bright life of Turkey and all the world. In this context, the study is expected to contribute to the literature in such a way that consumers can look at green marketing from a different perspective by bringing a fresh breath to the green product purchasing behaviour.

\section{References}

Arnt M. 2001. What'sin it forthecustomers? successfully marketing greenclothes. Business Strategyandthe Environment 10(5), 317-330.

Autio, M., Heinonen, V. 2004. Toconsumeor not toconsume?:youngpeople'senvironmetalism in theaffluentfinnishsociety. Journal of YouthResearch 12(2), 137-153.

Atay, L., Dilek, S. E. 2013. Konaklama işletmelerinde yeşil pazarlama uygulamaları: ibis otel örneği. Süleyman Demirel Üniversitesi İktisadi ve İdari Bilimler Fakültesi Dergisi 18(1), 203-219.

Ay, C., Ecevit, Z. 2005. Çevre bilinçli tüketiciler. Akdeniz Íktisadi ve İdari Bilimler Fakültesi Dergisi 5(10), 238-263.

Becken, S., Patterson, M. 2006. Measuringnationalcarbondioxideemissionsfromtourism as a key step towardsachievingsustainabletourism. Journal of Sustainable Tourism 14, 323328.

Cheah, I., Phau, I. 2011. Attitudes towards environmentally friendly products. Marketing Intelligence E Planning 29(5), 452-472.

Dagher, G. K., Itani, O. 2014. Factors influencing green purchasing behaviour: emprical evidence from the labanese consumers. Journal of Consumer Behaviour 13(3), 188-195.

Delmas, M. A., Burbano, V. G. 2011. Thedrivers of greenwashing. California Management Review, Berkeley 54(1), 64-87.

Easterling, D., Kenworthy, A., Nemzoff, R., College, B. 1996. Thegreening of advertising: a twenty-fiveyearlook at environmental advertising. Journal of Marketing Theory and Practice 4(1), 20-34.

Evren, S., Kozak, N. 2012. Eskisehir'inçekici faktörlerinin günübirlik ziyaretçilerin bakış açılarıyla değerlendirilmesi. Anatolia: Turizm Arastirmalari Dergisi 23(2), 220-232.

Gilg, A., Barr, S., Ford, N. 2005)Green consumption or sustainable lifestyle? İdentifying the sustainable consumer. Futures 37(6), 481-504.

Jain, S. K., Kaur, G. 2004. Green marketing: an attitudie behavioural analysis of indian consumers. Global Business Review 5(2), 187-205.

Jansson, J., Marell, A., Nordlund, A. 2010. Green consumer behavior: determinants of curtailmentan deco-innovation adoption. Journal of Consumer Marketin 27(4), 358-370.

Kalafatis, S. P., Pollard, M., East, R., Tsogas, M. H. 1999. Green marketing andajzen's theory of planned behaviour: a cross-market examination. Journal of Consumer Marketing 16(5), 441-46o.

Karaca, Ş. 2013.Tüketicilerin yeşil ürünlere ilişkin tutumlarının incelenmesine yönelik bir araştırma. Ege Akademik Bakış 13(1), 99-111. 
Khare, A., Mukerjee, S., Goyal, T. 2013. Social influence and green marketing: an exploratory study on indian consumers. Journal of Customer Behaviour 12(4), 361-381.

Minton, A. P., Rose, R. L. 1997. The effects of environmental concern on behavior: an exploratory study. Journal of Business Research 40(1), 37-48.

Mostafa, M. M. 2007. Gender differences in egyptian consumers. Green purchase behaviour: the effects of environmental knowledge, concern and attitude. International Journal of Consumer Studies 31(3), 220-229.

Ozkok, F. (2013) Turizm ve sürdürülebilirlik, ekoyapı ekolojik yapı ve yerleşimler dergisi, Vol: 10, Web: http://www.ekoyapidergisi.org/269-turizm-ve-surdurulebilirlik.htmlretrived on 8 December 2019.

Paço, A., Alves, H., Shiel, C., Filho, W. L. 2013. Development of a greenconsumerbehaviour model. International Journal of Consumer Studies 37(4), 414-421.

Park, S. Y., Sohn, S. H. 2012. Exploring the normative influences of social norms on individual environmental behavior. Journal of Global Scholars of Marketing Science 22(2), 183-194.

Peattie, K., Crane, A. 2005. Greenmarketing: legend, myth, farceorprophesy? Qualiative Market Research: An International Journal 8(4), 357-370.

Polonsky, M. J. 1994. An introductiontogreen marketing. Electronic Green Journal 1(2), 1-10.

Sharma, B. 2014. Consumer sattitudes, green practices, demographic and social influences, and government policies: an emprical investigation of the irrelationships. Journal of New Business Ideas \& Trends 12(2), 22-36.

Straughan, D. R., Roberts, J. A. 1999. Environmental segmentation alternatives: a look at green consumer behavior in the new millennium. Journal of Consumer Marketing 16(6), 558-575

Untaru, E. N., Epuran, G., Ispas, A. 2014. A conceptual framework of consumers pro-environmental attitudes and behaviours in the tourism context. Economic Science 56(2), 85-94.

Urry, J. 1995. Consuming places. London: Routledge.

Wahid, N. A., Rahbar, E., Shyan, T. S. 2011. Factors influencing the green purchase behavior of penang environmental voluntees. International Business Management 5(1), 38-49.

Xiao, C., McCright, A. M. 2015. Gender differences in environmental concern: Revisiting the institutional trust hypothesis in the USA. Environment and Behavior 47(1), 17-37.

Tsaur, S. H., Lin, Y. C., Lin, J. H. 2006. Evaluating ecotourism sustainability from the integrated perspective of resource, community and tourism. Tourism management 27(4), 640-653. 